\title{
Effects of Positive Behavior Support on Perceptions of School Quality
}

Hilda Sabbah

hildasabbah@yahoo.com

Paul Caldarella

Paul_Caldarella@byu.edu

Michael Richardson

michael_richardson@byu.edu

Ben Young

Follow this and additional works at: https://scholarsarchive.byu.edu/facpub

Part of the Teacher Education and Professional Development Commons

Original Publication Citation

Rocky Mountain Psychological Association, Park City, UT. (April 26)

\section{BYU ScholarsArchive Citation}

Sabbah, Hilda; Caldarella, Paul; Richardson, Michael; and Young, Ben, "Effects of Positive Behavior Support on Perceptions of School Quality" (2006). Faculty Publications. 1283.

https://scholarsarchive.byu.edu/facpub/1283

This Presentation is brought to you for free and open access by BYU ScholarsArchive. It has been accepted for inclusion in Faculty Publications by an authorized administrator of BYU ScholarsArchive. For more information, please contact ellen_amatangelo@byu.edu. 


\section{Effects of Positive Behavior Support on Perceptions of School Quality}

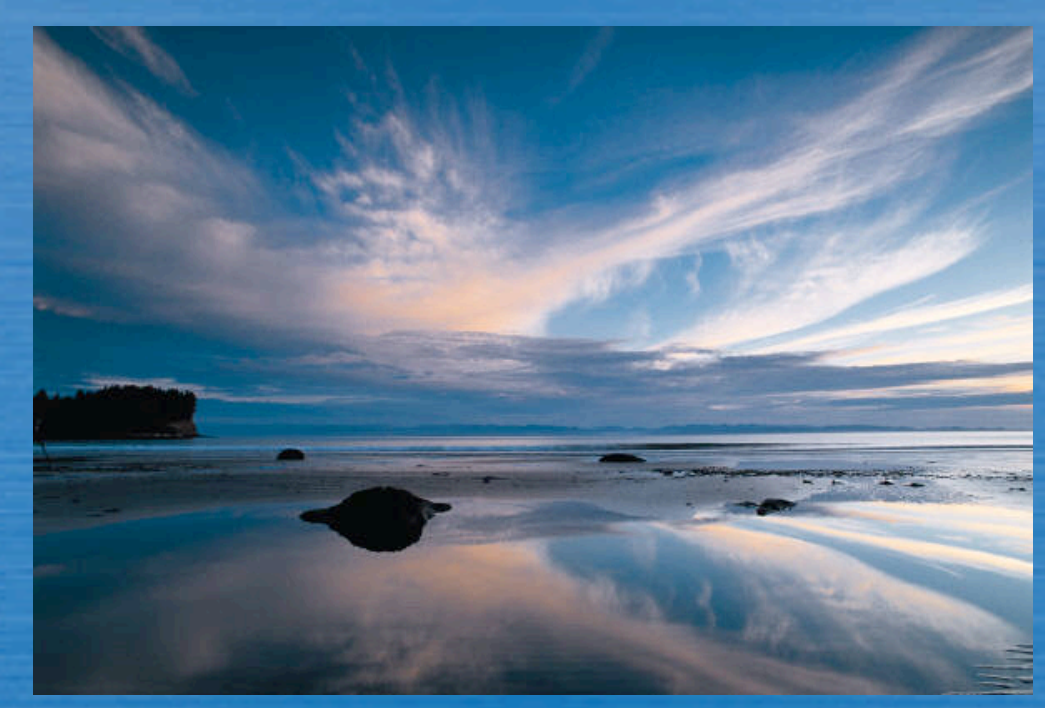

Presentation developed by the: BYU Peaceable Schools Staff McKay School of Education Brigham Young University 


\title{
Effects of Positive Behavior Support on Perceptions of School Quality
}

\author{
Hilda Sabbah \\ Paul Caldarella \\ Mike Richardson \\ Benjamin Young
}




\section{Indicators of School Quality (ISQ)}

ISQ is a comprehensive survey system for school administrators to evaluate and monitor school improvement and accreditation efforts. 


\section{ISQ}

ISQ is supported by research conducted in hundreds of schools and summarizes the perceptions of parents, teachers, students, and other school staff regarding:

- Parent Support

- Teacher Excellence

- Student Commitment

- School Leadership

- Instructional Quality

- Resource Management

- School Safety 


\section{ISQ}

The ISQ SURVEYS are

- Short

- Require a minimum amount of school time to complete

- They are age appropriate for both student and adult respondents

- They are available in both English and Spanish 


\section{STUDENT Survey}

\section{Indicators}

of School

Quality

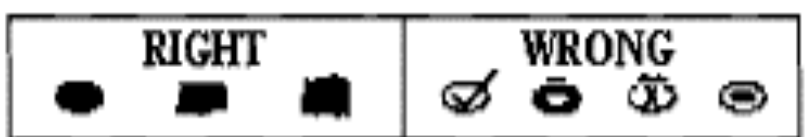

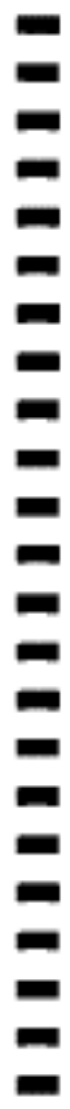

\section{Directions}

For each of the statements below, fill in the appropriate circle.

1. My parents help me with school

2. My parents know what happens to me at school

3. My teachers care about me.

4. My teachers enjoy teaching.

5.1 behave well in class.

6. I like to learn

7. My principal cares about me.

8. My principal helps me behave well.

9. I like my school.
School Name:

\begin{tabular}{|c|c|}
\hline 15. I am: & 16. I am in the: \\
\hline $\begin{array}{l}\text { African American } \\
\text { American Indian } \\
\text { Asian/Pacific Islander } \\
\text { Hispanic } \\
\text { White (Caucasian) } \\
\text { Other }\end{array}$ & $\begin{array}{l}\text { 2nd grade } \\
\text { 3rd grade } \\
\text { 4th grade } \\
\text { 5th grade } \\
6 \text { th grade } \\
\text { 7th grade } \\
\text { 8th grade }\end{array}$ \\
\hline $\begin{array}{l}\text { 17. I am a: } \\
\text { Boy } \square \text { Girl }\end{array}$ & \\
\hline
\end{tabular}

\section{Please answer the following:}

18. Has your family moved in the last year?

19. Do you have the Internet at home?

20. Does your teacher always give clear instructions? 


\section{ISQ}

ISQ is administered and collected once a year in the spring. Forms are filled out and distributed by teachers. Students take the ISQ home to parents to fill them out and bring them in sealed envelopes. However, students fill out the ISQ themselves in the classroom 


\section{ISQ}

\section{The ISQ REPORTS come in}

- Three varieties and are easy to read and easy to apply

- They provide information on the status of the school learning environment progress from year to year

- They also provide normative information about how a school compares to similar schools 


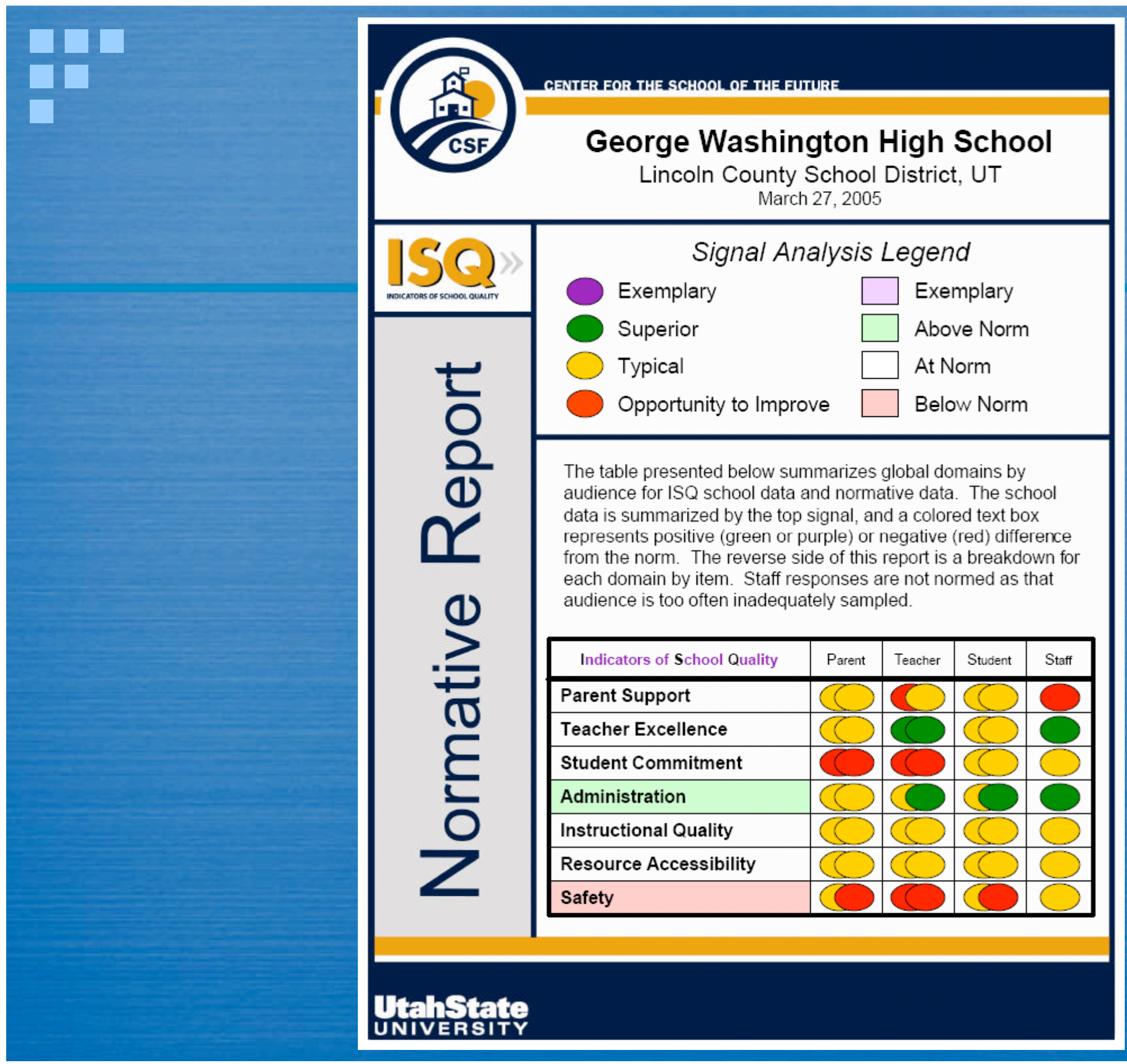




\section{Peaceable Schools \\ Supplementary Questions \& ISQ}

This study developed a new measure based on ISQ format, which was considered specifically relevant to the PBS model being implemented in the treatment schools. These supplementary questions were developed by Peaceable Schools team. 


\section{Objective of the Study}

The present study objective was to examine the effectiveness of school wide interventions using the ISQ and the supplement questions as measures of school climate. 


\section{Subjects of the Study}

Nine treatment

elementary schools

\&

Nine control

elementary schools 


\section{Data Collection}

Parents and teacher's data was collected for the past two years; 2004 \& 2005, while student's data was collected for one year only, 2005. 


\section{Methodology of Study}

Additional questions were administered in the ISQ format, which were considered specifically relevant to the PBS model being implemented in the treatment schools. These supplementary questions were developed by Peaceable Schools team. 


\section{Peaceable Schools Supplementary Questions}

The supplementary questions included items such as:

- Students receive written praise

- Students use appropriate social skills

- Behavior problems are dealt with appropriately 


\section{Analysis}

- Between-schools comparisons ( $t$-test) on each of the items for the second year the ISQ was administered

- Within-schools comparisons of ISQ results from year one to year two for treatment schools. 


\section{Results}

Results of this study are as follows:

- Parents and staff both typically rated the treatment schools higher than control schools on items where significant differences occurred. 


\section{Results - Parents}

"students are motivated to use appropriate social skills"

2004: $t=3.451, p=.001$

$\mathrm{N}: \mathrm{T}=1566$

$$
C=1781
$$

2005: $\mathrm{t}=4.231, p=.000$

$\mathrm{N}: \mathrm{T}=1229$

$C=1785$ 


\section{Results - Teachers}

"students are motivated to use appropriate social skills"

2004: $t=.523, p=.601$

$$
\begin{array}{r}
\mathrm{N}: \mathrm{T}=312 \\
\mathrm{C}=284
\end{array}
$$

2005: $t=3.316, p=.001$

$\mathrm{N}: \mathrm{T}=389$

$C=378$ 


\section{Results}

- Treatment schools were rated higher than the control schools by parents on the item "students received written praise" 


\section{Results - Students}

P

\begin{tabular}{|c|c|c|c|c|}
\hline & & $T$ & $N$ & $\mathbf{A l}$ \\
\hline \multirow{2}{*}{$\begin{array}{l}\mathrm{twS} \\
\mathrm{tw}\end{array}$} & & (1) & 3 & 3 \\
\hline & & 0 & 6 & 8 \\
\hline & $\overline{\mathrm{e}}$ & (1) & 8 & 0 \\
\hline & & 0 & 8 & $\mathbf{Z}$ \\
\hline \multirow{2}{*}{$\begin{array}{l} \\
a\end{array}$} & & (1) & 8 & 2 \\
\hline & & 0 & 8 & 8 \\
\hline \multirow{2}{*}{$\begin{array}{l}5 \\
6\end{array}$} & & (1) & 8 & 2 \\
\hline & & 0 & $\mathbf{g}$ & 0 \\
\hline
\end{tabular}

* $P<.05$ 


\section{Conclusions}

Treatment schools in this study showed variable gains in ratings relevant to the treatment suggesting:

- The intervention may have been implemented differently at treatment schools 


\section{Conclusions}

At least some aspects of the intervention were successfully implemented at the treatment schools 